\title{
ERRATUM
}

\section{Evidence that the dopamine D4 receptor is a susceptibility gene in attention deficit hyperactivity disorder}

SL Smalley, JN Bailey, CG Palmer, DP Cantwell, JJ McGough, MA Del'homme, JR Asarnow, JA Woodward, C Ramsey and SF Nelson. Mol Psychiatry 1998; 3: 427-430.

The term 'attributable risk' should be replaced by 'genotype relative risk' (Table 2 and pages 428,429) in the description of the estimate of relative risk attri- buted to the 7-repeat variant at the DRD4 locus and ADHD in this article. 